Article Type: Research Paper

\title{
The Effect of Fiscal Policy and Foreign Direct Investment on Regional Economy in Indonesia
}

\author{
Agus Tri Basuki*1, Yunastiti Purwaningsih², Albertus Maqnus Soesilo² \\ and Mulyanto ${ }^{2}$
}

\section{DPEN
ACCESS}

\section{AFFILIATION:}

${ }^{1}$ Ph.D. Student on Economics and Business Faculty Universitas Sebelas Maret Surakarta. Indonesia.

Universitas Muhammadiyah

Yogyakarta. Yogyakarta, Indonesia.

2 Universitas Sebelas Maret.

Surakarta, Indonesia

\section{*CORRESPONDENCE:}

agustribasuki@yahoo.com

\section{THIS ARTICLE IS AVALILABLE IN:}

http://journal.umy.ac.id/index.php/esp

DOI: 10.18196/jesp.21.1.5031

\section{CITATION:}

Basuki, A. T., Purwaningsih, Y., Soesilo, A. M., \& Mulyanto. (2020). The Effect of Fiscal Policy and Foreign Direct Investment on Regional Economy in Indonesia. Jurnal Ekonomi \& Studi Pembangunan, 21(1), 53-68.

\section{ARTICLE HISTORY}

Received:

25 November 2019

Reviewed:

31 March 2020

14 April 2020

Revised:

3 April 2020

14 April 2020

Accepted:

19 April 2020
Abstract: The purpose of this study was to analyze the influence of the poor population, government spending and foreign investment on regional economic growth in 20 provinces and divided into 2 regions, then compare the effectiveness of fiscal policies in the 2 regions. The paper utilizes the fixed effects and random - effects techniques to estimate the panel regressions. The results showed that the right fiscal policy could increase economic growth in both the western and eastern regions of Indonesia. For the western region, revenue sharing is less effective than the eastern region in increasing economic growth, but conversely government spending on education, health and marine in the western region is more effective than the eastern region in increasing economic growth.

Keywords: Economic growth; Panel data regression; Fiscal policy; Fiscal capacity. JEL Classification: B22; E62; F63.

\section{Introduction}

Economic development, according to Todaro (2000) it is defined as "the activities carried out by the state to develop economic activities to satisfy people's living standards." Economic development creates imbalances in some countries and does not solve fundamental development problems. It is evident in terms of level and quality of life among some disadvantaged and vulnerable people. Therefore, economic development can increase the ability of people to meet their needs, increase selfesteem as human beings, and uphold the human rights of society. Moreover, according to Boediono (1992), "Economic growth is a process of increasing output per capita in the long run." Thus, the percentage increase in output increase must be higher than the percentage increase in population, and there will be a long-term increase in economic growth.

The development process is not only determined by economic aspects but also is defined by other aspects, such as the economic policy of a region. Concerning the regional economy, it is defined as an increase in all the added value that happens, which is an increase in the overall revenue of the community that happens in the region (Tarigan, 2005). Regional 
income is a response to the factors of production in accordance with the prosperity of the region.

The factor affecting economic growth is that reducing the population of the poor will increase economic growth. The study of Škare and Družeta (2016) concludes that it is crucial for policymakers to ensure institutional pre-conditions and incorporate progrowth and pro-poor policies that will enable the poor to participate in opportunities and contribute to future growth. This paper represents a simple contribution to the analysis of the interdependence of poverty and economic growth and can serve as a basis for future research. Whereas Nindi and Odhiambo (2015) concluded that the results of the study indicated that economic growth did not cause poverty reduction in Swaziland, either in the short or long term. Instead, the study found a causal relationship from poverty reduction with economic growth in the short term.

Poverty makes the poor do not have access to resources and opportunities to invest so that it will slow down per capita economic growth (Todaro, 2000). Research on the relationship of the poor to economic growth has been carried out by Islam, Ghani, and Abidin (2017), Škare and Družeta (2016), Nindi and Odhiambo (2015), Sinnathurai (2013) and Afzal, Malik, Begum, Sarwar, and Fatima (2012). Islam et al. (2017) research concluded that the number of poor people had a positive relationship with economic growth, meaning that if the number of poor people increased, it would result in increased economic growth. Skare and Družeta (2016) research revealed that poverty growth did not reduce the level of economic development inequality. Research by Nindi and Odhiambo (2015), Sinnathurai (2013) and Afzal, M. et al. (2012) uncovered that the number of poor people had an inverse relationship with economic growth, meaning that if the number of poor people increased, it resulted in a decrease in economic growth.

Another factor affecting economic growth is that general allocation funds also contribute to economic growth. General Allocation Funds are funds that must be allocated by the central government to every province/district/city in Indonesia each year as development funds. It is a component of expenditure in the state budget and is a budget component in the budget used for development funds and should not be prioritized for routine transportation and only for development. However, the results of the study by Purbadharmaja, Ananda, and Santoso (2019) concluded that fiscal decentralization did not always lead to better budget management. The success of fiscal decentralization can be found in the quality of local budgets and the quality of budget management. The allocation of local budgets to improve public services and develop infrastructure will increase regional economic capacity. Enhancing the capacity of regional economies encourages community welfare.

Research on the relationship between the General Allocation Fund (DAU) on economic growth was done by Ahmad (2011). The results of the study inferred that the General Allocation Fund had a positive relationship with economic growth. Research conducted by Astria (2014) in South Sumatra showed the results that the General Allocation Fund had a negative influence on economic growth. Furthermore, Muti'ah's research (2017) 
found that that the balanced fund in the form of a General Allocation Fund had no impact on economic growth.

Then, another factor that can affect economic growth is fiscal policy. The fiscal policies carried out by the regional government are the regional budget and expenditure. The Regional Revenue and Expenditure Budget are prepared according to administrative needs and the ability of regional income. Fiscal policy can be used as a driver of economic activity and economic improvement (Udoh, 2011).

In addition to fiscal policy, the investment can also be relied on to foster development strategies that are strengthened with the national economy. The economic development effort in each region has the main objective to increase the numbers and types of employment opportunities for local communities. In an effort to achieve these goals, local governments and communities must jointly take Regional Development Assistance. The participation of local governments and communities using these resources has begun to inventory the potential of existing resources to support and develop the regional economy. Chaudhry, Mehmood, and Mehmood (2013); Abala (2014) support investment as one of the drivers of economic growth needed by traditional neoclassical opinions in economic development. According to this analysis, foreign investment is something that can save existing savings.

Based on Figure 1, the average economic growth in 2008 to 2017 was 7.94\%, with the highest economic growth achieved by Central Sulawesi and the lowest achieved by Nangro Aceh Darussalam. Meanwhile, the average growth in the Western Indonesia Region (Sumatra, Java, and Kalimantan) was $5.63 \%$, and the average growth in the Eastern Indonesia Region (Sulawesi, Nusa Tenggara, Maluku, and Papua) was $8.54 \%$.

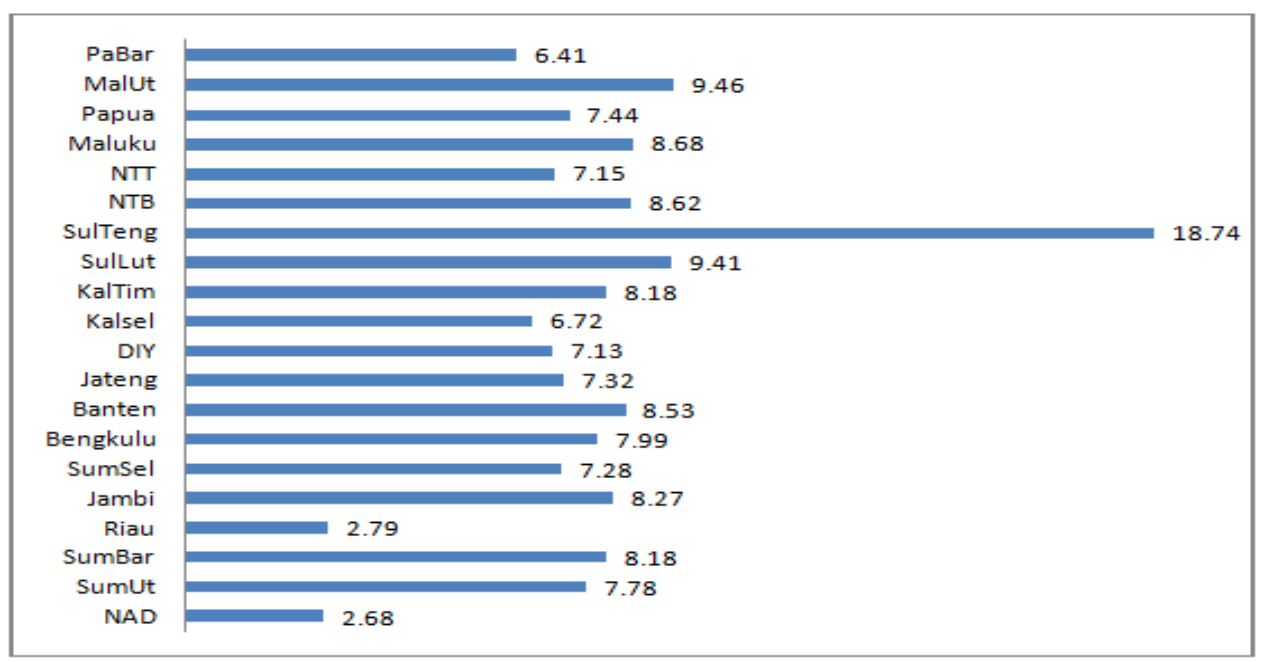

Figure 1 Average Economic Growth in 2008-2017 in various provinces in Indonesia Source: Indonesian Bureau of Statistics 
Figure 1 indicates that there was an imbalance in regional development in several provinces in Indonesia. One of the causes of inequality is that the allocation of funds can come from the government or the private sector. In the autonomous government system, more government funds will be allocated to the regions so that development disparities between regions will tend to be lower. Private investment is more determined by market forces, where the location advantage that is owned by an area is a force that has many roles in attracting private investment. The location advantage is determined by transportation cost, both raw materials and results to be paid by employers, differences in labor costs, market concentration, level of business competition, and land rent. Therefore, the investment will tend to be more in developed provinces compared to underdeveloped regions. These factors encourage to examine the influence of the poor, the allocation of development funds, government spending, and foreign investment in driving economic growth, as well as to investigate the role of fiscal policy in each region. Government expenditures used to influence the economic course of a region (infrastructure of education, health, transportation, and others) will result in increased economic activity and encourage economic growth (Todaro, 2000). Research on the effect of government spending on economic growth was conducted by Hussain, Khan, and Rafiq (2017), Udoh (2011), Oni, Aninkan, and Akinsanya (2014), and Surjaningsih, Utari, and Trisnanto (2012). The results of research by Hussain et al. (2017), Udoh (2011), and Oni et al. (2014) concluded that government spending had a positive influence on economic growth. Research from Surjaningsih et al. (2012) uncovered that in the long run, government spending had no effect on economic growth.

Meanwhile Bathla (2017) has conducted a study on the relationship between government spending on agriculture with economic growth. This research analyzed the relationship between public investment in agriculture and irrigation and agricultural growth in the Indian context. This analysis revealed that the formation of low and inadequate public capital during the nineties had an impact on farmers' investment and jeopardized technological change and agricultural growth. The major push in resource allocation for agriculture and irrigation from the early 2000 s was an essential policy initiative. Significant increases in spending on irrigation systems in less developed countries have helped curb productivity growth and stimulate private investment. However, capital intensity in agriculture did not increase significantly, which could partly explain the slow growth rate in many countries. The data showed that there were large variations between countries in public expenditure, implying that developed countries tended to spend more on agriculture compared to countries that depended on less developed agriculture. Thus, the empirical analysis indicated a significant impact on agricultural income.

Furthermore, this study aims to analyze regional independence and the effectiveness of regional fiscal policy in driving economic growth in western and eastern Indonesia. Through the application of fixed and random effects techniques in modeling the relationship between regional economic growth and the role of regional budgets and balancing funds, it is expected that regional economic performance can be measured and become a consideration of regional officials to take an important role in optimizing the use of local budgets. 


\section{Research Method}

The panel regression model in this study is as follows:

$$
\text { GRDP }=\beta_{0}+\beta_{1} \mathrm{Po}_{i t}+\beta_{2} \mathrm{DA}_{i t}+\beta_{3} \mathrm{Edu}_{\mathrm{it}}+\beta_{4} \mathrm{Hea}_{\mathrm{it}}+\beta_{5} \mathrm{Agri}_{\mathrm{it}}+\beta_{6} \mathrm{Ma}_{\mathrm{it}}+\beta_{7} \mathrm{FDI}_{\mathrm{it}}+\mathrm{e}
$$

The GRDP symbol is gross regional domestic income, $\beta$ is constant, $\beta(1,2 \ldots 7)$ is the regression coefficient of each independent variable, $P o$ is the number of poor populations, DA is the general allocation fund, Edu is the budget for education, Hea is the budget for health, Agric is a budget for agriculture, MA is a budget for fisheries and marine affairs, and FDI is foreign direct investment. $\mathrm{E}$ is Error term, $\mathrm{t}$ is Time from 2008 until 2018, and $i$ is the province. The sample of provinces involved was 20 provinces out of 34 provinces in Indonesia, while 14 provinces were incomplete data in the Ministry of Finance of the Republic of Indonesia. The data used in this study were sourced from the Central Bureau of Statistics of the Republic of Indonesia and the Ministry of Finance of the Republic of Indonesia from 2008 to 2017.

From equation 1 , the elasticity number can be found from the value of $\beta$ (equation 2 ). This $\beta$ value is obtained by logging (Gujarati, 2003: 168) of all variables except the variable whose value is percent or fraction.

$$
\begin{aligned}
\operatorname{LogGRDP}=\beta_{0}+\beta_{1} \operatorname{LogPo}_{i t}+ & \beta_{2} \operatorname{LogDA}_{i t}+\beta_{3} \operatorname{LogEdu}_{i t}+\beta_{4} \operatorname{LogHea}_{i t}+\beta_{5} \operatorname{LogAgri}_{i t}+\beta_{6} \operatorname{LogMA}_{i t} \\
& +\beta_{7} \operatorname{LogFDI}_{i t}+\mathrm{e}
\end{aligned}
$$

In the regression model estimation method using panel data, the analysis could be done through three approaches, including Common Effect Model, Fixed Effect Model, and Random Effect Model. After the equation was formed, the best model of the Common Effect Model, Fixed Effect Model, and Random Effect Model was selected by employing the Chow Test, Hausman Test, and LM Test. After the best model was chosen, then the classical assumption test was carried out. In the case of a classic assumption test, it is sufficient to utilize the heteroscedastic test and the multicollinearity test (Gujarati, 2003).

The stages of panel data analysis can be seen in Figure 2. The initial stages consisted of regression using the common effect, fixed effect, and random-effect methods. Then, the selection of the best models of the three models was conducted. The selected model would be tested for classical assumptions. After the step was completed, the next step was the analysis of the regression results of the selected model.

The data used in this study were sourced from the data of the Ministry of Finance of the Republic of Indonesia and the Indonesian Central Statistics Agency from 2008 to 2017. The provinces which were employed as samples were the Western part of Indonesia, namely; Central Kalimantan Province, South Kalimantan, DI Yogyakarta, Central Java, Banten, Bengkulu, South Sumatra, Jambi, Riau, West Sumatra, North Sumatra, and Aceh. Whereas, Eastern Indonesia comprised the Provinces of PaBar, MaLut, Papua, Maluku, NTT, NTB, SulTeng, and SuLut. 
Basuki, Purwaningsih, Soesilo, \& Mulyanto

The Effect of Fiscal Policy and Foreign Direct Investment ...

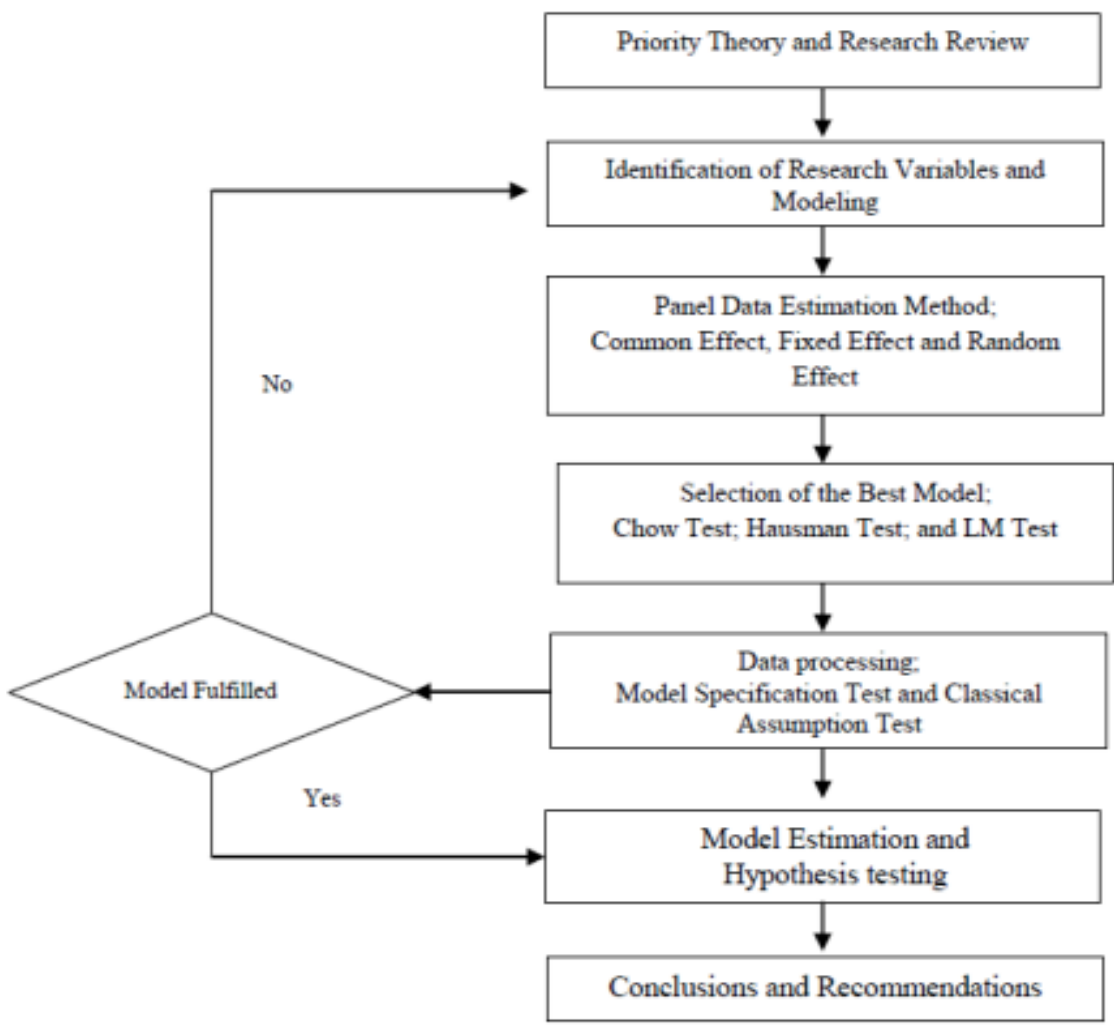

Figure 2 Panel Data Regression Stages

Source: Gujarati (2003)

\section{Result and Discussion}

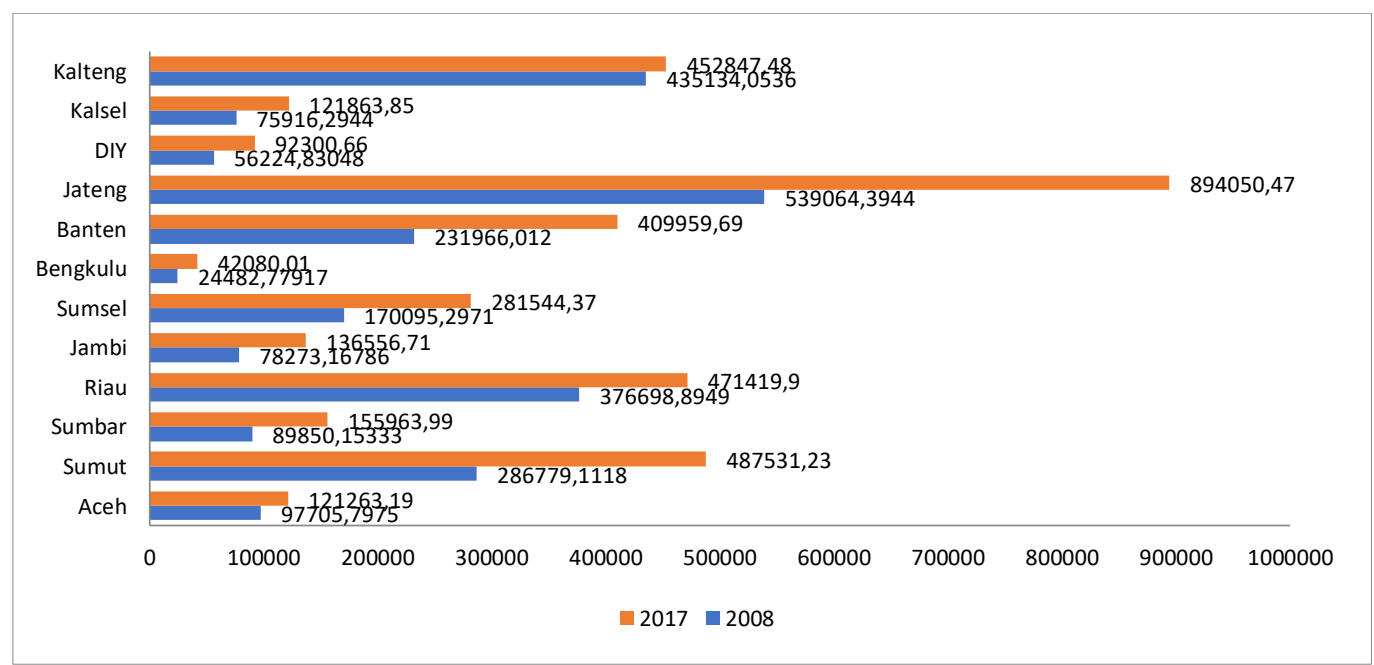

Figure 3 Development of GRDP in East Indonesian (Billion Rupiahs)

Source: Indonesia Bureau of Statistics Various Publication 2010, 2013, 2016, 2018

(processed) 
For the economic growth in western Indonesia (Sumatera, Jawa, and Kalimantan, see in Figure 3) from 2008 to 2017, the average economic growth was $56.34 \%$ (or an annual average of 5.63\%). The highest growth occurred in Banten Province, Jambi Province, and West Sumatra Province. Whereas the lowest growth occurred in Central Kalimantan Province, Aceh Province, and Riau Province. When viewed from natural resources owned by Banten Province, Jambi Province, and West Sumatra Province, they are far lower than natural resources owned by Central Kalimantan Province, Aceh Province, and Riau Province. In reality, economic growth exceeds the average growth of Indonesian and provincial economies that are rich in human resources.

Moreover, for the economic growth in Eastern Indonesia (Sulawesi, Nusa Tenggara, Maluku, and Papua see in Figure 4) from 2008 to 2017, the average economic growth was $85.38 \%$ (or an annual average of $8.54 \%$ ). The highest growth occurred in Central Sulawesi Province, North Sulawesi Province, and Maluku Provinces. Meanwhile, the lowest growth occurred in the provinces of West Papua, East Nusa Tenggara, and Papua (eastern Indonesia). The problem faced by the eastern part of Indonesia in economic development was that infrastructure problems between regions were not well connected, such as West Papua and Papua. Transportation in Papua mostly used air transportation because roads between districts were not yet well connected. Thus, it had an impact on the price of basic needs. Whereas, East Nusa Tenggara and Maluku are provinces whose territories are islands, so the primary transportation was sea transportation.

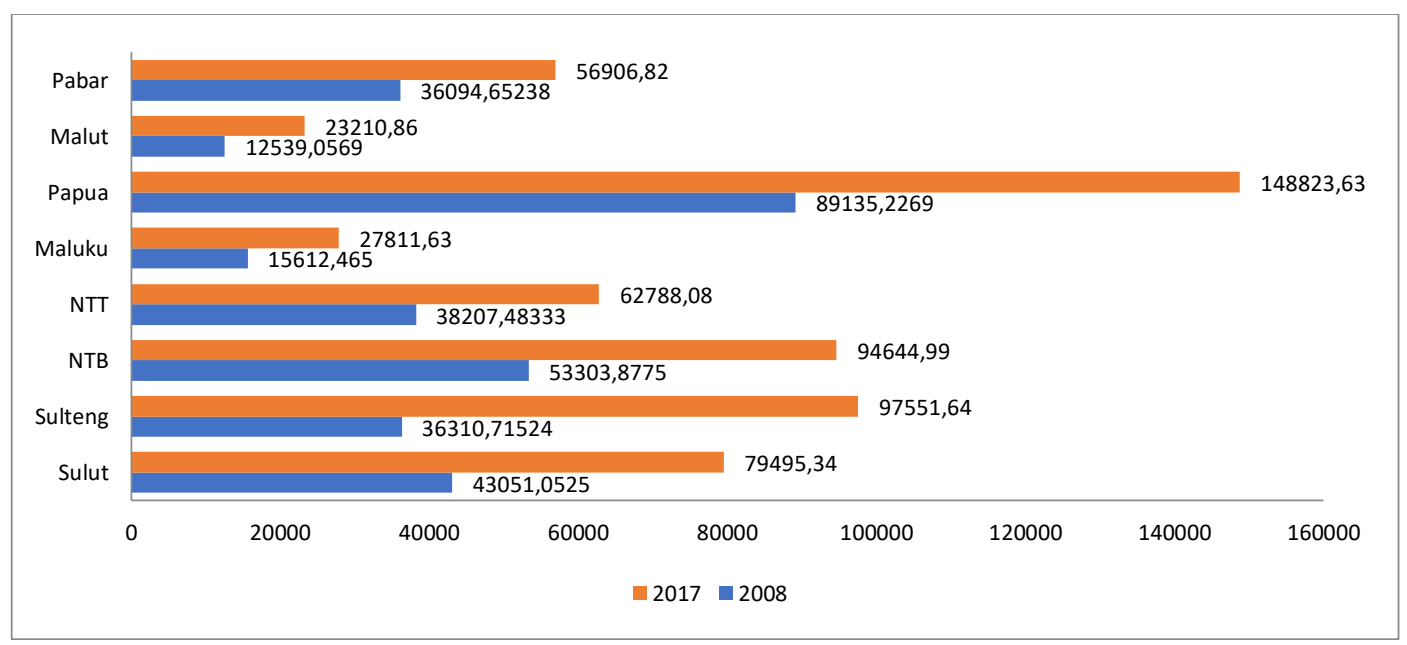

Figure 4 Development of GRDP in East Indonesian (Billion Rupiahs)

Source: Indonesia Bureau of Statistics Various Publication 2010, 2013, 2016, 2018 (processed)

From the description of Figure 3 and Figure 4, it is interesting to study what factors influenced economic growth in western and eastern Indonesia. Based on the panel data regression results listed in Table 1, the regression results obtained three models, namely the common effects model, the fixed effects model, and the random-effects model. 
Basuki, Purwaningsih, Soesilo, \& Mulyanto

The Effect of Fiscal Policy and Foreign Direct Investment ...

Table 1 Results of Panel Data Regression in Western and Eastern Indonesia

\begin{tabular}{|c|c|c|c|c|c|c|}
\hline \multirow{2}{*}{$\begin{array}{l}\text { Dependent } \\
\text { Variable }\end{array}$} & \multicolumn{3}{|c|}{ WEST INDONESIA } & \multicolumn{3}{|c|}{ EAST INDONESIA } \\
\hline & None & Fixed & Random & None & Fixed & Random \\
\hline Log (GRDP) & Effect & Effect & Effect & Effect & Effect & Effect \\
\hline \multirow[t]{3}{*}{ LOG(PO) } & 0.534 & -0.417 & -0.014 & 0.249 & -0.112 & 0.264 \\
\hline & (15.48 & $(-6.759)$ & $(-0.193)$ & (3.943) & $(-4.809)$ & (18.673) \\
\hline & 3) $* * *$ & $* * *$ & & $* * *$ & $* * *$ & $* * *$ \\
\hline \multirow[t]{4}{*}{ LOG(DA) } & -0.308 & 0.039 & 0.041 & 0.170 & 0.349 & 0.131 \\
\hline & $(-$ & (2.253) & (2.171) & (0.924) & $(27.277)$ & (3.261) \\
\hline & $6.512)$ & $* *$ & $* *$ & & $* * *$ & $* * *$ \\
\hline & $* * *$ & & & & & \\
\hline \multirow[t]{3}{*}{ LOG(EDU) } & 0.044 & 0.040 & 0.029 & 0.077 & 0.013 & 0.063 \\
\hline & (0.974) & (4.435) & (2.159) & (1.592) & (2.942) & (6.114) \\
\hline & & $* * *$ & $* *$ & & $* * *$ & $* * *$ \\
\hline \multirow[t]{3}{*}{ LOG(HEA) } & 0.161 & 0.113 & 0.125 & 0.039 & 0.003 & 0.023 \\
\hline & (2.985) & (5.590) & (4.799) & (1.267) & (2.156) & (3.723) \\
\hline & $* * *$ & $* * *$ & $* * *$ & & $* *$ & $* * *$ \\
\hline \multirow[t]{3}{*}{ LOG(AGRI) } & 0.107 & 0.014 & 0.028 & 0.387 & 0.016 & 0.386 \\
\hline & (2.236) & (0.943) & (1.531) & (3.884) & (2.440) & (17.139) \\
\hline & $* *$ & & & $* * *$ & $* *$ & $* * *$ \\
\hline \multirow[t]{3}{*}{ LOG(MA) } & 0.026 & 0.053 & 0.055 & -0.283 & -0.006 & -0.236 \\
\hline & (0.656) & $(4.000)$ & (3.379) & $(-3.300)$ & $(-1.245)$ & $(-12.796)$ \\
\hline & & $* * *$ & $* * *$ & $* * *$ & & $* * *$ \\
\hline \multirow[t]{3}{*}{ LOG(FDI) } & 0.180 & -0.001 & 0.012 & 0.085 & 0.025 & 0.087 \\
\hline & (12.53 & $(-0.256)$ & (2.110) & (3.550) & (13.207) & (15.868) \\
\hline & $8) * * *$ & & $* *$ & $* * *$ & $* * *$ & $* * *$ \\
\hline \multirow[t]{3}{*}{ C } & 20.225 & 31.561 & 25.338 & 15.476 & 21.928 & 15.970 \\
\hline & (18.75 & (26.043) & (19.912) & (4.631) & (47.920) & (21.011) \\
\hline & 4) $* * *$ & $* * *$ & $* * *$ & $* * *$ & $* * *$ & $* * *$ \\
\hline R-squared & 0.897 & 0.998 & 0.754 & 0.759 & 0.999 & 0.744 \\
\hline \multirow[t]{2}{*}{ F-statistic } & 140.03 & 4138.581 & 49.173 & 32.536 & 5731.942 & 30.049 \\
\hline & 3 & & & & & \\
\hline \multirow[t]{2}{*}{ Chow Test } & & $601.880 *$ & & & $2996.27 *$ & \\
\hline & & $* *$ & & & $* *$ & \\
\hline Hausman & & & $55.00 * * *$ & & & $1454.251^{*}$ \\
\hline Test & & & & & & $* *$ \\
\hline
\end{tabular}

Source: data processing results () t count

Note : *** significant $\alpha=1 \% \quad * *$ significant $\alpha=5 \% \quad *$ significant $\alpha=10 \%$

Of the three models above, the best model was chosen using the Chow test and Hausman test, and the test results that both produced the best model were the fixed effect model. After the best model was selected, the model was tested with the classical assumption test. The following are the results of the heteroscedasticity test employing a White test in which the independent variable was the squared residual. The results of the heteroscedasticity test (Table 2) showed that all independent variables were higher than the $5 \%$ significance level, indicating no heteroscedasticity in the model. 
Basuki, Purwaningsih, Soesilo, \& Mulyanto

The Effect of Fiscal Policy and Foreign Direct Investment ...

Table 2 Heteroscedasticity Test

\begin{tabular}{ccccc}
\hline $\begin{array}{c}\text { Dependent Variable } \\
\text { LOG(RESID^2) }\end{array}$ & \multicolumn{2}{c}{ West Indonesia } & \multicolumn{2}{c}{ East Indonesia } \\
\hline LOG(PO) & -0.659506 & 0.5110 & 1.938669 & 0.0569 \\
LOG(DA) & -1.307625 & 0.1939 & 1.167089 & 0.2474 \\
LOG(EDU) & 3.728530 & 0.0003 & 0.324498 & 0.7466 \\
\hline LOG(HEA) & -1.434936 & 0.1543 & 0.672470 & 0.5037 \\
\hline LOG(AGRI) & -0.188465 & 0.8509 & -0.067730 & 0.9462 \\
LOG(MA) & -0.953963 & 0.3423 & -1.122366 & 0.2658 \\
\hline LOG(FDI) & 0.142163 & 0.8872 & -0.229876 & 0.8189 \\
C & -0.115127 & 0.9086 & -1.999199 & 0.0498 \\
\hline
\end{tabular}

Source: Data processing results

The results of the multicollinearity test can be seen in Table 3, employing the matrix of correlation. If the correlation coefficient is above 0.85 , then there is multicollinearity in the model. Nevertheless, so far, all the coefficients were below 0.85 , indicating no multicollinearity.

Table 3 Multicollinearity Test

\begin{tabular}{|c|c|c|c|c|c|c|c|c|c|c|c|c|c|c|}
\hline \multirow{3}{*}{$\begin{array}{c}\text { Varia } \\
\text { ble }\end{array}$} & \multicolumn{7}{|c|}{ West Indonesia } & \multicolumn{7}{|c|}{ East Indonesia } \\
\hline & POV & EDU & HEA & AGR & MA & DAU & FDI & POV & EDU & HEA & AGR & MA & DAU & FDI \\
\hline & & & LT & 1 & $\mathrm{R}$ & & & & & LT & 1 & $\mathrm{R}$ & & \\
\hline \multirow[t]{3}{*}{ POV } & 1.0 & - & 0.4 & 0.3 & 0.0 & 0.4 & 0.0 & 1.0 & 0.1 & 0.3 & 0.3 & 0.0 & 0.3 & 0.1 \\
\hline & 00 & 0.06 & 49 & 46 & 82 & 74 & 26 & 00 & 27 & 85 & 81 & 36 & 12 & 94 \\
\hline & & 3 & & & & & & & & & & & & \\
\hline \multirow[t]{3}{*}{ EDU } & - & 1.0 & 0.4 & 0.3 & 0.6 & 0.3 & 0.1 & 0.1 & 1.0 & 0.5 & 0.5 & 0.6 & 0.4 & 0.1 \\
\hline & 0.06 & 00 & 62 & 70 & 84 & 65 & 98 & 27 & 00 & 77 & 85 & 78 & 89 & 75 \\
\hline & 3 & & & & & & & & & & & & & \\
\hline \multirow[t]{2}{*}{ HEALT } & 0.4 & 0.4 & 1.0 & 0.7 & 0.5 & 0.5 & 0.2 & 0.3 & 0.5 & 1.0 & 0.5 & 0.2 & 0.6 & 0.5 \\
\hline & 49 & 62 & 00 & 01 & 95 & 06 & 47 & 85 & 77 & 00 & 44 & 72 & 71 & 32 \\
\hline \multirow[t]{2}{*}{ AGRI } & 0.3 & 0.3 & 0.7 & 1.0 & 0.6 & 0.4 & 0.0 & 0.3 & 0.5 & 0.5 & 1.0 & 0.6 & 0.6 & 0.5 \\
\hline & 46 & 70 & 01 & 00 & 42 & 33 & 67 & 81 & 85 & 44 & 00 & 71 & 66 & 62 \\
\hline \multirow[t]{2}{*}{ MAR } & 0.0 & 0.6 & 0.5 & 0.6 & 1.0 & 0.3 & 0.0 & 0.0 & 0.6 & 0.2 & 0.6 & 1.0 & 0.6 & 0.3 \\
\hline & 82 & 84 & 95 & 42 & 00 & 67 & 58 & 36 & 78 & 72 & 71 & 00 & 19 & 29 \\
\hline \multirow[t]{2}{*}{ DAU } & 0.4 & 0.3 & 0.5 & 0.4 & 0.3 & 1.0 & 0.0 & 0.3 & 0.4 & 0.6 & 0.6 & 0.6 & 1.0 & 0.6 \\
\hline & 74 & 65 & 06 & 33 & 67 & 00 & 98 & 12 & 89 & 71 & 66 & 19 & 00 & 78 \\
\hline \multirow[t]{2}{*}{ FDI } & 0.0 & 0.1 & 0.2 & 0.0 & 0.0 & 0.0 & 1.0 & 0.1 & 0.1 & 0.5 & 0.5 & 0.3 & 0.6 & 1.0 \\
\hline & 26 & 98 & 47 & 67 & 58 & 98 & 00 & 94 & 75 & 32 & 62 & 29 & 78 & 00 \\
\hline
\end{tabular}

Source: data processing results

After the classic assumption test was carried out, it was necessary to test the Granger causality. Granger causality test is intended to determine the causal relationship of each independent variable on the dependent variable. In this study, Granger causality test was aimed more at the factors that influenced the GRDP growth rate, namely the poor population, general allocation funds, local government expenditure on education, regional government expenditure on health, regional government expenditure on agriculture and local government expenditure on maritime affairs, and investment foreign. 
Basuki, Purwaningsih, Soesilo, \& Mulyanto

The Effect of Fiscal Policy and Foreign Direct Investment ...

Table 4 Pairwise Granger Causality Test

\begin{tabular}{llcc}
\hline \multicolumn{1}{c}{ Null Hypothesis } & Obs & F-Statistic & Prob \\
\hline POV does not Grange Cause GRDP & 180 & 68.7333 & 0.0000 \\
GRDP does not Grange Cause POV & 180 & 2.57823 & 0.1101 \\
DAU does not Grange Cause GRDP & 180 & 21.5582 & 0.0000 \\
GRDP does not Grange Cause DAU & 180 & 8.98943 & 0.0031 \\
EDU does not Grange Cause GRDP & 180 & 4.16948 & 0.0426 \\
GRDP does not Grange Cause EDU & 180 & 1.33353 & 0.2497 \\
HEALTH does not Grange Cause GRDP & 180 & 1.52415 & 0.2186 \\
GRDP does not Grange Cause HEALTH & 180 & 5.95196 & 0.0157 \\
AGRI does not Grange Cause & 180 & 3.00920 & 0.0845 \\
GRDP does not Grange Cause AGRI & 180 & 7.34046 & 0.0074 \\
MAR does not Grange Cause GRDP & 180 & 1.19621 & 0.2756 \\
GRDP does not Grange Cause MAR & 180 & 0.12036 & 0.7291 \\
FDI does not Grange Cause GRDP & 180 & 2.21632 & 0.1383 \\
GRDP does not Grange Cause FDI & 180 & 12.4122 & 0.0005 \\
\hline
\end{tabular}

Source: Author, 2019

Based on Table 4, it is explained that the variables that had a granger causality relationship were variables with a probability value smaller than $a=0.05$, namely the expenditure on health, expenditures for agriculture and the General Allocation Fund. Whereas, the probability value, which was smaller than $a=0.1$, was the poor population, education expenditures and marine expenditures. As foreign investment did not have an influence toward the GRDP growth rate. Besides, the expenditures on health had a two-way relationship.

The analysis model in this study was divided into two models (Table 5), namely model 1 and model 2 for Western Indonesia and Eastern Indonesia, respectively. Model 1 and model 2 for Western Indonesia showed that all variables influenced economic growth, except the budget for the agricultural sector. For model 1, the number of poor people had a negative effect on economic growth. It means that if the number of poor people decreased by 1 percent, it would encourage economic growth by 0.41 percent. In this case, the poverty alleviation program is very effective in promoting economic growth.

The role of the general allocation fund for model 1 influenced economic growth, meaning that if there was an increase in the general allocation fund budget from the central government to regional governments by 1 percent, it would encourage economic growth by 0.039 percent. Whereas the role of budget policies for education, health, and marine affected economic growth, indicating that if the three budgets were raised by $1 \%$, it would encourage economic growth by $0.206 \%$. If the regional government of Western Indonesia wants to increase economic growth by $1 \%$, then the local government should increase the budget by $4.85 \%$. Besides, if model 2 was employed to increase $1 \%$ of economic growth, an additional $4.11 \%$ of the budget for education, health, and marine should be added to support the development program. 
Basuki, Purwaningsih, Soesilo, \& Mulyanto

The Effect of Fiscal Policy and Foreign Direct Investment ...

Table 5 Best Model Regression Results

\begin{tabular}{|c|c|c|c|c|}
\hline \multirow{3}{*}{$\begin{array}{c}\text { Dependent } \\
\text { Variable } \\
\text { LOG(GRDP) }\end{array}$} & \multicolumn{4}{|c|}{ Fixed Effect } \\
\hline & \multicolumn{2}{|c|}{ West Indonesia } & \multicolumn{2}{|c|}{ East Indonesia } \\
\hline & Model 1 & Model 2 & Model 1 & Model 2 \\
\hline \multirow[t]{2}{*}{ LOG(PO) } & -0.417 & & -0.112 & \\
\hline & $(-6.759) * * *$ & & $(-4.809) * * *$ & \\
\hline \multirow[t]{2}{*}{ LOG(DA) } & 0.039 & 0.052 & 0.349 & 0.440 \\
\hline & $(2.253) * *$ & $(2.477) * *$ & $(27.277) * * *$ & $(30.628) * * *$ \\
\hline \multirow[t]{2}{*}{ LOG(EDU) } & 0.040 & 0.033 & 0.013 & 0.0037 \\
\hline & $(4.435) * * *$ & $(2.845) * * *$ & $(2.942) * * *$ & (1.081) \\
\hline \multirow[t]{2}{*}{ LOG(HEA) } & 0.113 & 0.136 & 0.003 & 0.005 \\
\hline & $(5.590) * * *$ & $(6.764) * * *$ & $(2.156) * *$ & $(6.257) * * *$ \\
\hline \multirow[t]{2}{*}{ LOG(AGRI) } & 0.014 & 0.023 & 0.016 & 0.025 \\
\hline & $(0.943)$ & (1.404) & $(2.440) * *$ & $(3.890) * * *$ \\
\hline \multirow[t]{2}{*}{ LOG(MA) } & 0.053 & 0.074 & -0.006 & 0.007 \\
\hline & $(4.000) * * *$ & $(4.794) * * *$ & $(-1.245)$ & (1.635) \\
\hline \multirow[t]{2}{*}{ LOG(FDI) } & -0.001 & & 0.025 & \\
\hline & $(-0.256)$ & & $(13.207) * * *$ & \\
\hline \multirow[t]{2}{*}{$\mathrm{C}$} & 31.561 & 24.428 & 21.928 & 18.303 \\
\hline & $(26.043) * * *$ & $(54.965) * * *$ & $(47.920) * * *$ & $(44.109) * * *$ \\
\hline R-squared & 0.998 & 0.996 & 0.999 & 0.999 \\
\hline F-statistic & $4138.581 * * *$ & $2027.68 * * *$ & $5731.942 * * *$ & $6586.46 * * *$ \\
\hline
\end{tabular}

Source: Author, 2018

Note: ( ) t count ${ }^{* * *}$ significant $\alpha=1 \% * *$ significant $\alpha=5 \% *$ significant $\alpha=10 \%$

Foreign investment is considered to be something that can fill the gap between savings raised from within the country, foreign exchange reserves, government revenue, and expertise on the one hand and the amount needed to achieve development goals on the other hand (Todaro, 2000). Chaudhry et al. (2013) and Abala (2014) have carried out a study on the relationship between foreign investment and economic growth, indicating that foreign investment could have a positive relationship with economic growth.

Meanwhile, the role of foreign investment had a negative impact on economic growth. It means that if foreign investment increased by $1 \%$, it would cause economic growth to fall by $0.001 \%$. Although the effect was very small, the government should overcome this serious problem, because it would threaten macroeconomic stability. In line with Olabisi and Oloni's (2012) research uncovered that foreign investment had a negative relationship with growth.

Model 1 and model 2 for Eastern Indonesia showed that all variables had an effect on economic growth except the budget for the marine sector. For model 1 , the number of poor people negatively influenced economic growth. It means that if the number of poor people decreased by $1 \%$, it would encourage economic growth by $0.11 \%$. The poverty alleviation program in Eastern Indonesia was less effective compared to Western Indonesia, although the biggest problem for poverty in Indonesia was in the Eastern Indonesia region.

The role of the general allocation fund for model 1 in Eastern Indonesia affected economic growth. It indicated that if there was an increase in the budget, the general allocation fund from the central government to regional governments by $1 \%$, it would encourage 
economic growth by $0.349 \%$. The coefficient of the general fund allocation was higher than the coefficient in the western part of Indonesia, meaning that the dependence of the eastern part of Indonesia on the revenue sharing of the central and regional governments was very high. Meanwhile, the role of budget policies for education, health, and agriculture affected economic growth. If the three budgets were raised by $1 \%$, it would encourage economic growth by $0.032 \%$. If the government in Eastern Indonesia wants to increase economic growth by $1 \%$, then the local government should increase the budget by $31.25 \%$. Meanwhile, if employing model 2 to increase $1 \%$ of economic growth, an additional $33.33 \%$ of the budget for education, health, and agriculture was needed. Further, the role of foreign investment had a positive impact on economic growth. It means that if foreign investment increased by $1 \%$, it would cause an increase in the economic growth of $0.025 \%$.

Indonesia is a developing country, and the main problem is a large number of poor and unemployed people. Most poverty exists in Eastern Indonesia so that the efforts to reduce the number of poor people are prioritized for the eastern region. One way to overcome poverty is; First, the central government policy through the regional government guarantees a sense of security for vulnerable groups (female household heads, poor people, older people, neglected children, various abilities, and people with disabilities) and new poor people caused by natural disasters, or by the impact of the economic crisis and social conflict. Second, creating economic and social environmental conditions enables the poor to get the broadest possible opportunity to fulfill their rights and sustainably improve their living standards. Also, by providing pro-poor stimulation and regulation, the economic and social costs faced by them can be reduced. Besides, optimal services to improve the incomes of the poor can be provided.

Since 2000, Indonesia has implemented regional autonomy. Regional governments are given the right to carry out their economic development in accordance with the capabilities of each region. Based on the results of the analysis, there has been a gap between the use of revenue sharing funds between the central government and regional governments in western and eastern Indonesia. The dependence of eastern Indonesia on general allocation funds is very high compared to western Indonesia, so the independence of the provinces in eastern Indonesia is still very weak, or the source of funds for regional economic development is highly dependent on the central government. The higher the fiscal capacity of a region, the less dependence of the region on the allocation from the center. However, if the opposite occurs, then its dependence on transfers of funds from the center will be even higher. To overcome this problem, the use of general fund allocations should be used properly. Then, before the central government provides general allocation funds to local governments, it is necessary to look at the effectiveness of regional transfer funds in the development of a region. The government needs to ensure that general allocation funds can be used by local governments to encourage economic growth. The second problem is the management of fiscal policy; there has been a gap between Western Indonesia and Eastern Indonesia. The policy of employing the budget for education, health, agriculture, and marine is more effective in encouraging economic growth in Western Indonesia compared to Eastern Indonesia. 
Research on the relationship between government spending on education with economic growth has been carried out by Al-Shatti (2014), Grabova (2014), Idrees and Siddiqi (2013), Nworji, Okwu, Obiwuru, and Nworji (2012), Olabisi and Oloni (2012). The study conducted by Idrees and Siddiqi (2013) and Nworji et al. (2012) concluded that government spending on education had a positive influence toward economic development. Grabova's (2014) research revealed that government spending on education had a negative effect on economic growth. However, research by Al-Shafti (2014), Olabisi and Oloni (2012) found that government spending on education had no impact on economic growth.

The studies on the relationship between government spending on health with economic growth were done by Al-Shafti (2014) and Nworji et al. (2012). The study discovered that government spending on health had a positive influence toward economic growth in several countries.

Furthermore research on the relationship between government spending on maritime economic growth was conducted by Huda and Firdaus (2015) and Agustine (2014). The results of the study discovered that government spending on fisheries and marine affairs had a positive relationship with economic growth. The central government policy to reduce fiscal disparities between regions used the General Allocation Funds tool so that the region's ability to manage and develop regions was relatively and evenly distributed. This allocation system was established by Law No. 25 of 2000, which was later revised by Law No. 33 of 2004 concerning central and regional financial balances. Besides, the investigation on the relationship between the General Allocation Fund with economic growth was carried out by Ahmad (2011), Manik and Higayat (2010). The results of the study revealed that the General Allocation Fund had a positive relationship with economic growth. Furthermore, Muti'ah's (2017) research concluded that the balanced fund in the form of a General Allocation Fund had no effect on economic growth.

The gap between the use of revenue sharing funds between the central government and regional governments in western and eastern Indonesia is caused by the lack of human resources in Eastern Indonesia and the difficulty of transportation between regions in Eastern Indonesia. To overcome this problem, local governments are required to strengthen fiscal management to accelerate equitable growth. To run the program, there are three fiscal strategies used. The first strategy is optimizing regional income while maintaining the investment climate. The second one is spending efficiency and increasing productive spending to encourage economic growth while supporting efforts to reduce poverty, diminish inequality, and create employment. Also, the third strategy is encouraging innovative, sustainable, and efficient financing.

In addition, there is also a gap in the role of foreign investment in economic growth between western Indonesia and eastern Indonesia. For western Indonesia, foreign investment has a negative influence toward economic growth, but vice versa for foreign investment. However, Eastern Indonesia has a positive effect on economic growth. The government had an obligation to prioritize increasing foreign investment in eastern Indonesia because the increased foreign investment increases employment 
opportunities. Then, the presence of new factories has a positive impact on the domestic economy through the demand side: increasing employment opportunities, increasing the ability of public spending, and subsequently increasing demand in the domestic market. The role of foreign investment is becoming an essential source of technology and other knowledge transfer, through local workers working in foreign companies. When these workers move to domestic companies, they bring new knowledge or expertise from foreign companies to domestic companies.

\section{Conclusion}

Taking into consideration of empirical insights from this research, it could be concluded the government spending-economic growth nexus. First, the gap was in the use of general allocation funds, namely funds from the central government to regional governments. Local governments in eastern Indonesia relied more on general allocation funds in promoting economic development through the accuracy of using development programs rather than local governments in western Indonesia. Eastern Indonesia is more dependent on equalization funds from the central government to local governments to encourage economic growth compared to western Indonesia. To overcome the gap between central and regional financial dependencies in driving economic growth between western and eastern Indonesia, the following steps need to be taken; in stipulating revenue sharing between the center and the regions, priority must be given to capital expenditure compared to personnel expenditure, and for additional employee expenditure, it is better to prioritize to be funded by regional taxes and regional user fees. Thus, if the budget allocation for capital expenditure through the balance funds from the central government rises, an increase in capital expenditure will encourage the rate of economic growth.

Another factor influencing local government dependence on general allocation funds is the lack of involvement of regional companies as a source of revenue. Local governments also need to conduct policies that are conducive to the development of companies into professional companies, and operationally monitor and evaluate the performance of key companies that can encourage competitiveness. Decentralization creates autonomous regions that depend on central government transfers to regional governments. Second, the gap is in the ability to use development programs through fiscal policy. Programs through fiscal policy in western Indonesia are more effective in driving economic growth than eastern Indonesia. The step to overcoming this is the need for synergy between the central government and regional governments to integrate the central government budget with the regional government budget. Cooperation between fiscal authorities is essential that regional budgets should become instruments to reduce unemployment, poverty, inequality, and realize equitable development.

The role of foreign investment is more effectively developed in eastern Indonesia compared to western Indonesia, so the central government needs to prioritize facilities and infrastructure in encouraging foreign investment into eastern Indonesia. It can be achieved by improving good and integrated physical infrastructure and superstructure in various regions in Indonesia; developing human resources by opening various formal and 
non-formal educational institutions; creating legal certainty and deregulating some regulations which hinder investment; providing incentives for the business community in the form of regional levies tax relief; and giving the ease of licensing services and the certainty of investment licensing supervision, so that entrepreneurs and investors are not disadvantaged.

\section{References}

Abala, D.O. (2014). Foreign Direct Investment and Economic Growth: An Empirical Analysis of Kenyan Data. DBA Africa Management Review, 4(1), 62-83.

https://doi.org/10.11648/j.ijefm.20160403.13

Afzal, M., Malik, M. E., Begum, I., Sarwar, K., \& Fatima, H. (2012). Relationship among Education, Poverty and Economic Growth in Pakistan: An Econometric Analysis. Journal of Elementary Education, 22(1), 23-45. Retrieved from http://pu.edu.pk/images/journal/JEE/PDFFiles/3 Afzal malik ishrat $\% 20$ final 2012JEE Vol 22 no 1.pdf

Agustine, A. D. (2014). Pengembangan Sektor Kelautan dan Perikanan Untuk Meningkatkan Pendapatan Asli Daerah (Studi di Dinas Kelautan dan Perikanan Kabupaten Banyuwangi). Jurnal Administrasi Publike, 2(2), 276-280. Retrieved from https://media.neliti.com/media/publications/77702-ID-pengembangan-sektorkelautan-dan-perikan.pdf

Ahmad, I. (2011). Regional Fiscal Independence in East Java Province Post Regional Autonomy. Economic Journal of Emerging Markets, 3(2), 189-198. https://doi.org/10.20885/ejem.v3i2.2330

Al-Shatti, A.S. (2014). The Impact of Public Expenditures on Economic Growth in Jordan. International Journal of economics and Finance, 6(10), 157. https://doi.org/10.5539/ijef.v6n10p157

Astria, S. A. (2014). Analisis Pengaruh Dana Alokasi Umum Dan Belanja Modal Terhadap Pertumbuhan Ekonomi Di Sumatera Selatan. Journal Ekonomi Pembangunan, 12(1), 4154. https://doi.org/10.29259/jep.v12i1.4867

Bathla, S. (2017). Public Investment in Agriculture and Growth: An Analysis of Relationship in the Indian Context. Changing Contours of Indian Agriculture, 13-28. https://doi.org/10.1007/978-981-10-6014-4_2

Boediono. (1981). Teori Pertumbuhan Ekonomi. Yogyakarta: BPFE.

Chaudhry, N. I., Mehmood, A., \& Mehmood, M. S. (2013). Empirical Relationship Between Foreign Direct Investment and Economic Growth. China Finance Review International. 3 (1), 26-41. https:// doi.org/10.1108/20441391311290767

Grabova, P. (2014). Corruption impact on Economic Growth: An empirical analysis. Journal of Economic Development, Management, IT, Finance, and Marketing, 6(2), 57.

Gujarati, D. (2003). Basic Econometrics. Forth Edition. Singapore: McGraw-Hill.

Huda, H. M., Purnamadewi, Y. L., \& Firdaus, M. (2015). Industrialisasi Perikanan Dalam Pengembangan Wilayah di Jawa Timur. TATALOKA, 17(2), 99-112. https://doi.org/10.14710/tataloka.17.2.99-112

Hussain, I. H., Khan, Z., \& Rafiq, M. (2017). An Empirical Analysis of The Impact of Compositional Changes in Public Expenditure on Economic Growth: Time Series Evidence from Pakistan. Business \& Economic Review, 9(1), 1-20. https://doi.org/10.22547/ber/9.1.1 
Basuki, Purwaningsih, Soesilo, \& Mulyanto

The Effect of Fiscal Policy and Foreign Direct Investment ...

Idrees, A. S., \& Siddiqi, M. W. (2013). Does Public Education Expenditure Cause Economic Growth? Comparison of Developed and Developing Countries. Pakistan Journal of Commerce and Social Sciences (PJCSS), 7(1), 174-183. Retrieved from http://www.jespk.net/publications/116.pdf

Islam, R., Ghani, A.B.A., Abidin, I.Z. and Rayaiappan, J.M., (2017). Impact on Poverty and Income Inequality in Malaysia's Economic Growth. Problems and Perspectives in Management, 15(1), 55-62. https://doi.org/10.21511/ppm.15(1).2017.05

Manik, R.E. and Hidayat, P., (2010). Analisis Dampak Desentralisasi Fiskal Terhadap Pertumbuhan Ekonomi Kabupaten/kota Pemekaran di Sumatera Utara. Jumal Keuangan \& Bisnis Program Studi Magister Manajemen Sekolah Tinggi Ilmu Ekonomi Harapan, 2(3), 217-226.

Muti'ah. (2017). The Effect of Regional Revenue, Revenue Sharing Fund, General Allocation Fund and Special Allocation Fund on Regional Economic Growth (Empirical Study In the 33 provinces in Indonesia Year 2011-2014). Research Journal of Finance and Accounting. 8(8), 102-112. Retrieved from https://www.iiste.org/Journals/index.php/RJFA/article/view/36777

Nindi, A. G., \& Odhiambo, N. M. (2015). Poverty and Economic Growth in Swaziland: An Empirical Investigation. Managing Global Transitions: International Research Journal, 13(1), 59-74. Retrieved from http://www.fm-kp.si/zalozba/issn/1581-6311/13 059074.pdf

Nworji, I. D., Okwu, A. T., Obiwuru, T. C., \& Nworji, L. O. (2012). Effects of Public Expenditure on Economic Growth in Nigeria: A Disaggregated Time Series Analysis. International Journal of Management Sciences and Business Research, 1(7), 1-15. Retrieved from http://www.ijmsbr.com/Volume $\% 201$,Issue $\% 207 \% 20(6) \% 20$ Andy.pdf

Olabisi, A. S., \& Oloni, E. F. (2012). Composition of Public Expenditure and Economic Growth in Nigeria. Journal of Emerging Trends in Economics and Management Sciences, 3(4), 403-407. Retrieved from

http://citeseerx.ist.psu.edu/viewdoc/download;jsessionid=66B37A953FD3161F2C9 014ED21DE60D9?doi=10.1.1.300.5903\&rep $=$ rep1\&type $=$ pdf

Purbadharmaja, I. B. P., Ananda, C. F., \& Santoso, D. B. (2019). The Implications Of Fiscal Decentralization And Budget Governance On Economic Capacity And Community Welfare. foresight. 21(2), 227-249. https://doi.org/10.1108/fs-05-2018-0052

Oni, L. B., Aninkan, O. O., \& Akinsanya, T. A. (2014). Joint Effects of Capital and Recurrent Expenditures in Nigeria's Economic Growth. European Journal of Globalization and Development Research, 9(1), 530-543.

Sinnathurai, V. (2013). An Empirical Study on The Nexus of Poverty, GDP Growth, Dependency Ratio and Employment in Developing Countries. Journal of Competitiveness. 5 (2), 67-82. https://doi.org/10.7441/joc.2013.02.05

Škare, M., \& Družeta, R. P. (2016). Poverty and Economic Growth: A Review. Technological and Economic Development of Economy, 22(1), 156-175. https://doi.org/10.3846/20294913.2015.1125965

Surjaningsih, N., Utari, G.D. \& Trisnanto, B., (2012). Dampak Kebijakan Fiskal Terhadap Output dan Inflasi. Buletin Ekonomi Moneter dan Perbankan, 14(4), 389-420. https://doi.org/10.21098/bemp.v14i4.365

Tarigan, R. (2005). Ekonomi Regional Teori dan Aplikasi Edisi Revisi. Jakarta: Bumi aksara. Todaro, M. P. (2000). Economic Development. New York University. New York.

Udoh, E. (2011). An Examination of Public Expenditure, Private Investment and Agricultural Sector Growth in Nigeria: Bounds Testing Approach. International Journal of Business and Social Science, 2(13), 285-292. Retrieved from https://ijbssnet.com/journals/Vol._2 No. 13 Special_Issue_July 2011/34.pdf 